acquired. The rapprochement of scientific and cultural or human interests in this way is an outstanding achievement of the Institution.

\section{Conference on College Hygiene}

THE second National Conference on College Hygiene of the United States will be held in Washington, D.C., on December 28-31 under the joint sponsorship of the American Student Association, the National Health Council and the President's Committee of Fifteen on College Hygiene. There will be no formal programme, but the work will be divided into five sections devoted respectively to health service, health teaching, organization and correlation, special problems and relationship of college hygiene to training and secondary education. Dr. Livingston Farrand, president of Cornell University, from whom further information can be obtained, is chairman of the Conference.

\section{Indian Science Abstracts}

THE National Institute of Sciences of India has recently issued the first number of Indian Science Abstracts, an annotated bibliography of science in India, including abstracts of all papers published in India or abroad on work done in India or based on Indian material. The first part includes abstracts arranged tentatively under nine headings. To ensure continuity under each heading and to facilitate reference, the abstracts dealing with each science have been given a separate pagination with the serial number of the heading preceding it. The abstracts in each section are arranged alphabetically and numbered serially. The general editor is Dr. Baini Prashad, who is assisted by nine associate editors for different subjects.

\section{Announcements}

Dr. Hans von Euler-Chelpin, professor of organic chemistry at Stockholm, has been elected an honorary member of the Association of German Chemists ; the Justus Liebig Medal of the Association has been awarded to Dr. Gustav Hittig, professor of inorganic and analytical chemistry at the German Technical University at Prague; and the Carl Duisberg Memorial Prize to Dr. Rudolf Tschesche, of Göttingen.

A PRIzE of 1,000 dollars is offered by the Williams and Wilkins Publishing Company for the best work on a science subject presented before July 1, 1937 . The work must be in English and the desired length is 100,000 words. Further information can be obtained from the Company, Mt. Royal and Guilford Avenue, Baltimore, Maryland.

DuRING the forthcoming winter, Mr. H. V. Garner, the guide demonstrator of the Rothamsted Experimental Station, Harpenden, Herts, and other members of the staff, are prepared to give a few lectures to chambers of agriculture and horticulture, farmers' clubs, farm workers' associations, agricultural societies, etc., on the Rothamsted experiments. Among the subjects offered are: manures, fertilizers, soil micro-organisms (Bacteria, Protozoa, etc.), agricul- tural botany, agricultural chemistry, soil physies, entomology, and plant pathology. Further information can be obtained from the Secretary, Rothamsted Experimental Station, Harpenden, Herts.

Mr. W. J. HALL, of Walsall, who was formerly with the Wool Industries Research Association at Leeds, and later with British Celanese Ltd., has been appointed technical editor of the Journal of the Textile Institute.

Messrs. Adlard AND Son, LTd., presented to members of the British Association at Blackpool a handy pocket diary, the main part of which consists of a calendar (September 1936-July 1937) of the meetings of scientific societies. Copies of the little book can be obtained from Messrs. Adlard at 21 Hart Street, London, W.C.1, price $6 d$.

Applications are invited for the following appoint. ments, on or before the dates mentioned :

A principal of Llanelly New Mining and Technical Institute - The Clerk of the Education Committee, County Education Offices, Carmarthen (September 28).

An assistant lecturer in mathematics in the Huddersfield Technical College-The Director of Education, Education Offices, Peel Street, Huddersfield (September 30).

An assistant lecturer in metallurgy in University College, Swansea-The Registrar (September 30).

An assistant (Grade III) in the Air Ministry Scientific Pool, for service at the Royal Aircraft Establishment, South Farnborough-Chief Superintendent, Royal Aircraft Establishment, quoting Ref. A.248 (October 2).

An assistant keeper on the higher technical staff of the Science Divisions of the Science Museum-The Director, Science Museum, South Kensington, London, S.W.7 (October 12).

An assistant county dairy instructor for Hampshire-County Agricultural Organizer, The Castle, Winchester (October 12).

A chemist in the Aeronautical Inspection Directorate Test House, Kidbrooke (non-metallic materials section, oils and petrols sub-section)-Secretary, Air Ministry (S.2.d.), Adastral House, Kingsway, W.C.2 (October 24).

A director of the Kanematsu Memorial Institute of Pathology, Sydney Hospital, N.S.W.--Secretary, Universities' Bureau, 88a Gower Street, London, W.C.1 (January 31).

Assistants to civil and mechanical engineers in the Ordnance Factories, E.D.(F.), Royal Arsenal, Woolwich, S.E.18-The Chief Superintendent.

A male junior assistant chemist at the Royal Gunpowder Factory, Waltham Abbey, Enfield Lock, Middlesex-Principal Clerk.

Temporary assistant civil engineers in the Air Ministry-Secretary (W.B.9), Room 712, Adastral House, Air Ministry, Kingsway, W.C.2, by post-card for form of application.

A male laboratory assistant (Grade II) at the Experimental Station, Porton, near Salisbury, of the War Department-Commandant of the Station. 